\title{
Choroby duszy i ciała człowieka według brytyjskich i irlandzkich ksiąg pokutnych
}

Dzięki działalności mnichów iroszkockich w starożytności chrześcijańskiej zaczęły powstawać księgi pokutne. Mogą być one nazywane taryfikatorami pokutnymi, ponieważ zawierały pokuty, które nakładane miały być podczas spowiedzi. Oprócz tego dokumenty te dostarczają wiedzy na temat kondycji duchowej i społecznej ludzi żyjących na przełomie późnego antyku i wczesnego średniowiecza. $Z$ tego powodu penitencjały moga nakreślić obraz „chorób duszy” i schorzeń ciała dotykających ówczesnych chrześcijan. W tym artykule zostaną poddane analizie wybrane kanony ksiąg brytyjskich i irlandzkich, a więc najstarszych z zachowanych penitencjałów związanych z zaproponowanym tematem.

Księgi pokutne łacińskie dzieli się na trzy grupy ze względu na terytorium, na którym powstały. Oprócz wspomnianych ksiąg brytyjskich i irlandzkich są także księgi galijskie i italskie oraz księgi hiszpańskie. Penitencjały używane w Kościele Iroszkockim datowane są na okres od VI do VIII wieku, chociaż datacja poszczególnych ksiąg bywa przesuwana na czas od V do IX wieku. Na kontynencie praktyka korzystania z ksiąg pokutnych przyjęła się później, dlatego powstawanie tamtejszych ksiąg określa się na okres od VIII do XI wieku. W tym opracowaniu jako źródła posłużyły niektóre z zachowanych penitencjałów irlandzkich i brytyjskich: Capitula Dacheriana, Capitula Theodori, De diversitate culparum Kolumbana, Discipulus Umbriensium, Excarpsum de canonibus catholicorum Patrum vel Poenitential ad remedium animarum domini Egberti archiepiscopi Eburacae civitatis, Paenitentiale quod dicitur Bigotianum, Paenitentiale Sancti Columbani, Poenitentiale Cummaeani, Poenitentiale

1 Ks. mgr lic. Wojciech Witowski, doktorant, Sekcja Historii Kościoła i Patrologii, Wydział Teologii Katolickiego Uniwersytetu Lubelskiego Jana Pawła II; email: w.witowski@gmail.com; ORCID: 0000-0001-5475-7947. 
Pseudo-Cummaeani, Poenitentiale Vinniani, Sancti Egberti Eboracensis archiepiscopi poenitentiale libri V, Synodusalia S. Patricii.

Autor, przez analizowanie wybranych kanonów wymienionych penitencjałów, odpowie na następujące pytania badawcze: w jakim kontekście pojawiają się choroby w źródłach, czym jest „choroba duszy”, w jaki sposób choroby fizyczne wpływały na praktyki pokutne chrześcijan. Celem artykułu jest przedstawienie rozumienia chorób duszy i ciała według autorów źródłowej literatury penitencjalnej.

\section{Choroba duszy - grzech}

W literaturze dotyczącej pierwszych wieków chrześcijaństwa można natrafić na określenie „fenomen iroszkocki” " Jednym z przejawów wyjątkowości Kościoła powstałego w Irlandii, nazywanej insula doctorum albo insula sanctorum, była gorliwość w życiu pokutnym polegająca także na częstej spowiedzi sakramentalnej ${ }^{3}$. Pomocą w sprawowaniu tego sakramentu miały być księgi pokutne (libri poenitentiales), podręczniki duszpasterskie oraz zbiory norm prawnych, które powstawały w konsekwencji wymogów stawianych przez lokalne synody ${ }^{4}$.

2 Por. J. Strzelczyk, Iroszkoci w kulturze średniowiecznej Europy, Warszawa 1987, s. 12.

3 Por. J. Daniélou - H.I. Marrou, Historia Kościoła, Od początków do roku 600, t. 1, tł. M. Tarnowska, Warszawa 1986, s. 337. Irlandzkie podejście do pokuty, która polegała na częstym wyznawaniu win podczas sakramentalnej spowiedzi indywidualnej i powtarzalnej formie pokuty, wyrażało wyraźną różnicę pomiędzy „chrześcijaństwem wyspiarskim” a „chrześcijaństwem kontynentalnym”. W Europie praktykowano najczęściej jednorazową, surową pokutę publiczną. Szerzej na temat praktyki pokutnej Kościoła w Europie Zachodniej, zob. B. Kosecki, Wyznanie grzechów w praktyce pokuty Kościoła na Zachodzie, „Ruch Biblijny i Liturgiczny” 29/2-3 (1976) s. 65-81; M. Kieling, Grzech i pokuta a świadomość świętości w późnej starożytności chrześcijańskiej, „Teologia Patrystyczna" 1 (2004) s. 43-54. O korzystaniu z ksiąg pokutnych, zob. M. Kieling, Zasady ogólne dotyczace praktyk pokutnych na podstawie „Libri poenitentales”, „Vox Patrum" 67 (2017) s. 225-240.

4 Por. D. Kwiatkowski, Rzeczywistość grzechu i praktyki pokutne w Paenitentiale Vigilianum (Albeldense), „Liturgia Sacra” 18/1 (2002) s. 116-117. Początkowo pokuta taryfowa oparta na księgach pokutnych była odrzucana na kontynencie (np. w Hiszpanii przez III Synod w Toledo w 589 roku), z czasem jednak została przyjęta (np. w Galii przez Synod w Chàlon-sur-Saóne obradujący w latach 639-654). Świadectwem przyjęcia formy pokuty od Iroszkotów są powstające w kolejnych latach księgi pokutne galijskie, italskie i hiszpańskie. Szerzej na temat kontrowersji związanych z pokutą taryfową, zob. 
Jako dzieła związane z życiem sakramentalnym i duchowym chrześcijan księgi pokutne przywołują pojęcie choroby najpierw w znaczeniu duchowym. W takim kontekście na oznaczenie choroby używany jest termin morbus ${ }^{5}$. W Księdze pokutnej św. Kolumbana, która powstała w VI wieku, autor zestawia choroby duchowe z chorobami fizycznymi:

W związku z różnorodnością win, różne są również kary. Tak samo przecież i leczący ciała przepisują lekarstwa według różnych zasad. Inaczej leczą rany, inaczej choroby, jeszcze inaczej wzdęcia, siność, inaczej gangrenę, anemię, złamania i oparzenia. Podobnie lekarze ducha duchowe schorzenia (animarum vulnera): choroby, winy, bóle, niedomagania i słabości powinni leczyć różnymi metodami ${ }^{6}$.

Autor cytowanego penitencjału, pokazując, że różne wymienionego przez niego choroby ciała leczy się w różny sposób, chce uświadomić, że także różne rodzaje chorób duchowych wymagają różnego rodzaju pomocy. Przez chorobę duchową należy rozumieć popełniony grzech ${ }^{7}$. Słowa te znajdują się na początku księgi i mają tłumaczyć, dlaczego na różne grzechy przypisane zostały różne pokuty. Jest to świadectwo in-

W. Zawadzki, Bernharda Poschmanna nauka o pokucie wczesnośredniowiecznej, „Studia Warmińskie" 47 (2010) s. 187-189. O wpływie Iroszkotów na Europę, zob. T. Cahill, How the Irish saved civilizaion. The Untold Story of Ireland's Heroic Role from the Fall of Rome to the Rise of Medieval Europe, New York 1995, s. 145-196.

5 Warto zauważyć, że gdy mowa jest o chorobie duchowej w księgach pokutnych, zazwyczaj używany jest rzeczownik morbus, gdy natomiast autorzy wspominają choroby ciała, najczęściej używają słowa infirmitas (lub rzadziej aegritas). Jest to o tyle zaskakujące, że Słownik kościelny łacińsko-polski przy haśle infirmitas podaje następujące znaczenia: „słabość, choroba, skłonność do grzechu”, co sugerowałoby użycie go w kontekście choroby duchowej, a przy haśle morbus podane są jedynie znaczenia, jak „choroba, słabość, objawy choroby”. Por. A. Jougan, Słownik kościelny łacińsko-polski, Sandomierz 2013, s. 336, 432.

6 Paenitentiale Sancti Columbani, B [Prologus], tł. S. Kalinkowski, Księga pokutna św. Kolumbana, w: Księgi pokutne (tekst łaciński, grecki i polski), opr. A. Baron - H. Pietras, Synody i Kolekcje Praw 5, ŹMT 58, Kraków 2011, s. 32-33.

7 Trzeba zauważyć, że dla autorów penitencjałów choroba fizyczna nie jest następstwem popełnionego grzechu w rozumieniu biblijnym. Autorzy rozróżniają choroby duchowe od fizycznych, o czym świadczy także wspomniane stosowanie różnych pojęć. Porównanie grzechu do choroby w sensie duchowym ma pomóc w rozumieniu, czym jest grzech, jakie niesie konsekwencje i jak należy go leczyć. Szerzej na temat choroby jako konsekwencji grzechu, zob. A.J. Katolo, Koncepcje zdrowia i choroby w starożytnej kulturze klasycznej $i$ w ujęciu biblijnym. Próba porównania, „Studia Gdańskie” 24 (2009) s. 203-208. 
dywidualnego podejścia do każdego człowieka, który przystępował do sakramentu pokuty. Z jednej strony każda choroba wymagała innego lekarstwa, ale jak pokazuje wstęp do Wyciagu Egberta, księgi powstałej w VIII wieku, także każdy penitent zasługiwał na indywidualne podejście i zbadanie sytuacji:

Nie należy wszystkich osądzać według tej samej miary, nawet jeśli dopuścili się jednego występku, ale wszystko należy rozróżnić, to znaczy, pomiędzy bogatym i biednym, [że jest] wolny, niewolnik, dziecko, chłopiec, młodzieniec, dorosły, w podeszłym wieku, ułomny, gnuśny, świecki, duchowny, mnich, biskup, prezbiter, diakon, subdiakon, lektor, osoba pełniąca jakieś funkcje i bez nich, małżonek i bezżenny, cudzoziemiec, dziewica, kobieta w klasztorze czy Bogu poświęcona, słaby, chory, zdrowy; jakich dotyczy zwierząt czy ludzi, wstrzemięźliwi czy niewstrzemięźliwi, dobrowolnie czy przypadkiem, w miejscu publicznym czy w ukryciu, jak zostanie odpokutowany, z konieczności czy dobrowolnie, miejsce i czas ${ }^{8}$.

Powyższe słowa, które stanowią wskazówkę i zachętę dla duszpasterzy mających sprawować sakrament pokuty, bardzo wyraźnie świadczą o indywidualnym traktowaniu każdej spowiedzi. Nakładane pokuty różniły się ze względu na rodzaj popełnionego grzechu, ale także ze względu na okoliczności towarzyszące popełnieniu grzesznej czynności. Takie podejście do sakramentu pokuty jest obecne w teologii moralnej także i dzisiaj, gdy okoliczności popełnienia grzechu wpływają na jego ciężar9.

8 Excarpsum de canonibus catholicorum Patrum vel Poenitential ad remedium animarum domini Egberti archiepiscopi Eburacae civitatis, [Prologus], t1. A. Baron A. Caba, Wyciag z kanonów Ojców katolickich lub pokutne środki lecznicze dla dusz, arcybiskupa Egberta z Yorku, ŹMT 58, s. 182. Przytoczony cytat poprzedzony jest zamieszczeniem rozróżnienia chorób duszy i ciała, podobnie jak we wspomnianej wyżej Księdze pokutnej św. Kolumbana.

9 W penitencjałach znaleźć można miejsca, w których okoliczności zmieniają nałożoną pokutę bardzo znacznie, np. przy okazji popełnienia morderstwa podczas wojny pod wodzą prawowitego króla nałożona pokuta trwała 40 dni a nie kilka lub kilkanaście lat jak za „zwykłe” zabójstwo. Por. Poenitentiale Pseudo-Cummaeani VI 7, tł. A. Baron - J. Łukaszewska-Haberko - H. Pietras, Księga pokutna PseudoKummeana, w: Księgi pokutne (tekst taciński, grecki i polski), opr. A. Baron H. Pietras, Synody i Kolekcje Praw 5, ŹMT 58, Kraków 2011, s. 100. Szerzej o indywidualnym podejściu do penitenta od starożytności chrześcijańskiej, zob. M. Worbs, Leczniczy charakter sakramentu pokuty, w: Wiara a zdrowie (II), red. L. Sochocka - M. Worbs, Opole 2016, s. 92-93. 
We fragmencie datowanym na VIII wiek księgi Penitencjat zwany Bigotianum wyraźnie widać, że pojawiające się określenie „choroba duchowa" jest synonimem grzechu:

O tyle większa skuteczność lekarza, o ile bardziej wzmogła się choroba pacjenta. Stąd zajmujący się leczeniem ran innych, uważnie winni uwzględniać, w jakim wieku i jakiej płci jest grzesznik, jakie otrzymał wykształcenie, jak jest dzielny, jaki kłopot przywiódł go do grzechu, jakie cierpienie go dręczy, jak długi czas trwał w przyjemnościach, jaki smutek i trud go trapią i jak odsuwa się od spraw świata. [...] Ludzie mądrzy winni mieć na uwadze w ustalaniu miary pokuty, by zbrodni zasługującej na miecz nie karali kijem, a grzechu zasługującego na kij nie przebijali mieczem ${ }^{10}$.

Skoro grzesznik nazywany jest w tym fragmencie pacjentem, który zachorował, można wyciągnąć wniosek, że pod pojęciem choroby kryje się grzech. Autor podkreśla także konieczność stosowania adekwatnej pokuty, w zależności od wielkości popełnionego występku. Poszczególne grzechy są dokładnie nazywane i omawiane przez autorów penitencjałów. Pojęcie choroby duchowej może w księgach pokutnych oznaczać każdy grzech, który, gdy było to potrzebne, autorzy nazywali konkretnie. Dwukrotnie pojawia się także doprecyzowane pojęcie choroby. Raz mowa jest o chorobie pychy (morbus superbiae) ${ }^{11}$, w drugim przypadku - o chorobie chciwości (morbus avaritiae), która jest korzeniem wszelkiego zła ${ }^{12}$.

Gdy grzesznik, chorujący na duszy z powodu popełnionego grzechu, zgłaszał się do kapłana, ten stawał się dla cierpiącego lekarzem, który powinien mu pomóc. By leczenie było możliwe, spowiednik musiał być odpowiednio przygotowany, żeby dobrać właściwe lekarstwo do konkretnej sytuacji ${ }^{13}$.

10 Paenitentiale quod dicitur Bigotianum 1-3, tł. A. Caba, Penitencjał zwany Bigotianum, ŹMT 58, s. 249.

11 Por. Columbanus, De diversitate culparum 15, tł. S. Kalinkowski, Kolumban, O różnych przewinieniach, ŹMT 58, s. 47.

12 Por. Capitula Theodori XIII 1, tł. A. Baron - A. Caba, Rozdziały Teodora, ŹMT 58, s. 167.

13 Por. Poenitentiale Vinniani, [Finis], tł. A. Baron - J. Łukaszewska-Haberko H. Pietras, Księga Pokutna Finniana, ŹMT 58, s. 23. Oprócz spowiednika w niektórych sytuacjach za lekarza dusz mógł być uważany ten, który krytykował uporczywie drugich, jeśli czynił to w celu nagany zła i potwierdzenia dobra albo z powodu współczucia. Jeśli motywy jego postępowania byłby inne, zasługiwał na ukaranie. Por. Poenitentiale Cummaeani VIII 16, tł. A. Baron - J. Łukaszewska-Haberko - H. Pietras, Księga pokutna Kummeana, ŹMT 58, s. 79. 
W penitencjałach jako lekarstwo na grzechy wymieniana jest przede wszystkim pokuta. Takie słowa zostały przypisane Teodorowi, biskupowi Canterbury, w datowanej na VII wiek księdze Discipulus Umbriensium:

Po pierwsze, najdrożsi, ze względu na troskę o waszą szczęśliwość postanowiłem dogłębnie wyjaśnić, skąd zostały zaczerpnięte poniższe środki lecznicze (fomenta medicaminis), [...] gdyż przenośnie jego [prawa] pierwszym projektantem był Bóg, który powierzył je ojcom, aby nauczyli go swoich synów, aby nowe pokolenie je znało, to znaczy pokutę, którą na początku swojej misji dla nas wszystkich głosił Pan Jezus jako lekarstwo dla źle się mających, mówiąc: Czyńcie pokutę i następne ${ }^{14}$.

Autor, odwołując się do słów Ewangelii, uzasadnia, że Bóg powierzył swoim uczniom pokutę jako środek leczniczy na grzechy popełniane przez ludzi. Takie ogólne stwierdzenie znajduje się także w innych księgach pokutnych. Poszczególne kanony precyzują, jakie pokuty powinny być nakładane za konkretne przewinienia, by mogły odnieść pożądany skutek, a więc uzdrowić chorującego na duszy. To miało być celem zadośćuczynienia, które grzesznik zobowiązywał się wypełnić po sakramentalnej spowiedzi.

Kummean, autor jednej z ksiąg pokutnych z VII wieku, a za nim i inni, jak Egbert z VIII wieku, przedstawił listę dwunastu środków leczniczych na rany duchowe, opierając się na tekstach Pisma Świętego. Według niego lekarstwami na grzech są przyjęcie chrztu świętego, okazywanie miłości, czynienie jałmużny, przelanie łez, wyznanie win podczas spowiedzi, praktykowanie umartwienia serca i ciał, zmiana obyczajów przez odrzucenie wad, wspomożenie świętych, czynienie miłosierdzia i zasługa wiary, nawrócenie i ocalenie innych, przebaczenie i odpuszczenie innym, poniesienie męczeństwa ${ }^{15}$. Każdy z wymienionych sposobów był oparty na fragmencie biblijnym. Po ich wyliczeniu autor przechodzi do opisania pokut, które powinny być nakładane za popełnienie ośmiu grzechów głównych. Wstępem do tego są słowa:

14 Discipulus Umbriensium, [Prologus], tł. A. Baron, Discipulus Umbriensium, ŹMT 58, s. 131-132.

15 Por. Poenitentiale Cummaeani, [Prologus], 1-13, tł. A. Baron - J. ŁukaszewskaHaberko - H. Pietras, Księga pokutna Kummeana, ŹMT 58, s. 70-71. Szerzej na temat dwunastu sposobów odpuszczenia grzechów na przykładzie analizy Penitencjału Egberta, zob. M. Kieling, Dwanaście sposobów odpuszczenia grzechów? Praktyka pokutna wczesnośredniowiecznego Kościoła na podstawie „Penitencjału Egberta”, „Teologia praktyczna" 13 (2012) s. 83-95. 
Ustalili zatem [ojcowie] osiem grzechów głównych, przeciwnych ludzkiemu zbawieniu i leczyć je można ośmioma przeciwnościami. Mówi bowiem dawne przysłowie: Przeciwne leczy się przeciwnym. Kto chętnie popełniał rzeczy niedozwolone, winien dobrowolnie powstrzymywać się od dozwolonych ${ }^{16}$.

Fragment ten poświadcza istnienie katalogu ośmiu grzechów głównych ${ }^{17}$, które powinny być leczone przeciwnymi im cnotami. Taka forma walki ze słabościami wydaje się być tożsama z siódmym sposobem odpuszczenia win, czyli ze zmianą obyczajów polegającą na odrzuceniu wad. Jednak w dalszej części penitencjału autor wymienia szczegółowo, jakie pokuty związane są z popełnieniem kolejnych grzechów głównych. Sugeruje to, że grzechy uważane za główne mogły być odpuszczane podczas wyznania win (confessio) w czasie sakramentu pokuty. Pozostałe z dwunastu sposobów odpuszczania grzechów mogły być skuteczne w przypadku popełnienia grzechów lekkich i jako środki pomocne w osobistej pracy nad sobą.

Chrześcijanin, który po popełnieniu grzechów wyznał je spowiednikowi i otrzymał rozgrzeszenie, był dopuszczany do przyjęcia Komunii Świętej. Przyjmowanie Ciała Chrystusa również było uważane za lekarstwo, nie tyle w przypadku choroby duchowej, jaką był grzech, ale bardziej jako środek pomagający w walce z grzechami. Świadectwem tego są słowa m.in. z Drugiego Synodu świętego Patryka:

Po wyznaniu grzechów należy przyjąć ciało Pana, zwłaszcza w noc paschalną, w którą ten, kto nie przyjmuje komunii, nie jest wiernym. Dlatego krótkie i ścisłe są u nich okresy postu, aby wierna dusza nie zginęła pozbawiona tego lekarstwa, ponieważ Pan powiedział: Jeśli nie będziecie spożywać ciała Syna Człowieczego, nie będziecie mieli życia w sobie ${ }^{18}$.

16 Poenitentiale Cummaeani, [Prologus], 15, t1. A. Baron- J. Łukaszewska-Haberko - H. Pietras, Księga pokutna Kummeana, ŹMT 58, s. 71.

17 Za twórcę podziału na osiem grzechów głównych (pochodzących od ośmiu duchów zła) uważa się Ewangriusza z Pontu. Zaliczył on do nich: obżarstwo, nieczystość, chciwość, smutek, gniew, acedię, próżność i pychę. Szerzej na ten temat, zob. L. Misiarczyk, Osiem duchów zła i sposoby walki z nimi według Ewagriusza z Pontu, Kraków 2015, s. 17-108.

18 Synodus alia S. Patricii 22, tł. B. Frontczak, Drugi synod świętego Patryka, ŹMT 58, s. 69. 
Dyscyplina pokutna Kościoła Iroszkockiego dopuszczała grzesznika już po wyznaniu win do przyjmowania Komunii Świętej. Nawet nakazane było przyjmowanie Eucharystii w czasie Wigilii Paschalnej. Widać wyraźnie różnicę w praktykach pokutnych w Irlandii oraz w Europie kontynentalnej, gdzie pokutnicy często przez długi czas byli pozbawiani przyjmowania Ciała Chrystusa. W Kościele irlandzkim przystępowanie do Komunii było nie tylko przywilejem świętych, ale też uważane było za lekarstwo chroniące przed popełnianiem przyszłych grzechów, dlatego zwracano uwagę by nie było zbyty długich przerw między przyjmowaniem Eucharystii, co mogłoby prowadzić do duchowego upadku.

Księgi pokutne, jako dzieła podejmujące przede wszystkim tematykę życia religijnego ówczesnych chrześcijan, w wielu miejscach porównują grzech do choroby duchowej, która dotyka grzesznika. Chorujący z tego powodu nie jest pozostawiony sam sobie, ale może udać się do lekarza spowiednika, który w oparciu o pouczenia Pisma Świętego i zapisy penitencjałów znajdzie odpowiednie lekarstwo pomocne w uzdrowieniu duszy grzesznika. Możliwości spowiedzi nie można było odmówić nikomu ${ }^{19}$.

\section{Choroby fizyczne}

Oprócz chorób duchowych w penitencjałach wspomniane są także choroby fizyczne. Nie są to jednak główne tematy tych utworów, dlatego wzmianki o nich możemy odnaleźć niejako przy okazji głównych wątków. Samo wymienienie nazw różnych chorób odbywa się przy porównywaniu grzechu do niedomagania fizycznego. Z przytoczonego wyżej fragmentu dowiadujemy się o rozróżnianiu następujących chorób: odniesione rany, wzdęcia, siność, gangrena, anemia, złamania, oparzenia ${ }^{20}$. Autorzy nie opisują dokładnie sposobów leczenia tych dolegliwości, wspominając jedy-

19 Prawdziwym uzdrowieniem było powstanie z grzechów, które było dostępne dla każdego grzesznika: „Biskupowi i kapłanowi nie przystoi odmówić spowiedzi tym, którzy jej pragną, nawet gdyby w bardzo wielu czynach dopuścili się grzechów, ponieważ miłosierdzie Boga jest takie, że żaden człowiek mu nie dorówna. Mówi prorok w imię Ducha Świętego: Kiedy grzesznik nawraca się ze swoich grzechów do skruchy, wtedy zostanie uzdrowiony, i dalej: Wyznaj swa nieprawość, abyś zyskat usprawiedliwienie" (Sancti Egberti Eboracensis archiepiscopi poenitentiale libri V I/2, 7-9, t1. A. Baron J. Łukaszewska-Haberko - H. Pietras, Penitencjat św. Egberta arcybiskupa Yorku w pięciu księgach, ŹMT 58, s. 219).

20 Por. Paenitentiale Sancti Columbani, B [Prologus], tł. S. Kalinkowski, Księga pokutna św. Kolumbana, ŹMT 58, s. 32-33. 
nie, że „leczący ciała przepisują różne lekarstwa i wywary na różne choroby (diversitatem infirmitatum)"21.

Podczas omawiania różnych grzechów pojawiają się także opisy leczenia, które uważane są za grzeszne. Pierwszym z takich przypadków, opisanym m.in. w Księdze pokutnej Pseudo-Kummeana, jest sytuacja, gdy kobieta próbuje zażywać jako lekarstwo krew swojego męża: „Żona, która skosztowałaby krwi swego męża jako lekarstwa, niech pokutuje 40 dni"'22. Autor nie precyzuje, przy jakich dolegliwościach miałby być stosowany taki rodzaj leczenia. Być może związane jest to z przejętym jeszcze z przedchrześcijańskich czasów przekonaniem, że spożywanie krwi mogło przynosić specjalne korzyści, jak np. oczyszczenie albo dodanie sił ${ }^{23}$. Drugi przypadek został opisany w Penitencjale Egberta przy omawianiu pokut za czary: „Jeśli kobieta umieści swoją córkę na dachu lub nad piecem, bo chciała wyleczyć jej gorączkę, niech pości 7 lat" ${ }^{24}$. Trudno zrozumieć, jaki efekt miałyby przynieść takie próby lecznicze, ale zapewne były związane z jakimiś przesądami lub namowami ze strony wróżbitów. Już od starożytności gorączka była różnie interpretowana, w zależności od okresu i regionu: albo jako objaw pozytywny, czasem wręcz pożądany, a czasem jako negatywna oznaka, np. gniewu bóstw ${ }^{25}$. $Z$ omawianego kanonu wynika jednak jasno, że korzystanie z czarów, nawet do leczenia dolegliwości, związane było z koniecznością odbycia długotrwałej pokuty.

Dwukrotnie w brytyjskich i irlandzkich księgach pokutnych pojawia się pojęcie zarazy (pestis). Teodor w Capitula Dacheriana przy omawianiu zwyczajów Greków i Rzymian wspomina: „O śmiertelnej zarazie Grecy i Rzymianie mówią, że tych chorych trzeba odwiedzać tak jak pozostałych chorych, jak przykazał Pan" ${ }^{26}$. Autor nie precyzuje, o doświadczeniu jakiej zarazy mówi, jednak w starożytności zdarzały się wyniszczające epide-

21 Excarpsum de canonibus catholicorum Patrum vel Poenitential ad remedium animarum domini Egberti archiepiscopi Eburacae civitatis, [Prologus], t1. A. BaronA. Caba, Wyciag z kanonów Ojców katolickich lub pokutne środki lecznicze dla dusz, arcybiskupa Egberta z Yorku, ŹMT 58, s. 181.

22 Por. Poenitentiale Pseudo-Cummaeani I 35, tł. A. Baron - J. ŁukaszewskaHaberko - H. Pietras, Księga pokutna Pseudo-Kummeana, ŹMT 58, s. 90.

23 Por. A.M. Wołek, Metaforyka i symbolika krwi w tradycji antycznej, w: Źródła Humanistyki Europejskiej, t. 6, red. K. Korus, Kraków 2013, s. 213.

24 Sancti Egberti Eboracensis archiepiscopi poenitentiale libri V I/1, 33, ŹMT 58, s. 213.

25 Por. A.S. El-Radhi, History of Fever, w: Clinical Manual of Fever in Children, red. J. Caroll - A.S. El-Radhi - N. Klein, Berlin 2009, s. 287-298.

26 Capitula Dacheriana 24, tł. A. Caba, Capitula Dacheriana, ŹMT 58, s. 117. 
mie. Możliwe, że kanon ten nawiązuje do tzw. Dżumy Justyniana, która wybuchła w Cesarstwie Wschodniorzymskim w 541 roku, a miała rozprzestrzeniać się na obszarze od Persji po Irlandię ${ }^{27}$. Według badaczy źródeł historycznych kolejne fale epidemii miały pojawiać się w VI, VII i VIII wieku, a w sumie zaraza mogła pochłonąć nawet do 100 milionów ludzi. Długofalowe skutki tej epidemii dla Europy były bardzo duże, a autor penitencjału powstałego w VII wieku mógł być tego naocznym świadkiem. Treść cytowanego kanonu potwierdza wysoki poziom życia religijnego tamtych czasów, ponieważ wzywa do heroicznego okazywania miłosierdzia wobec zarażonych osób, co mogło stanowić narażenie własnego życia.

Kolejny raz choroba została wspomniana w kanonie mówiącym o możliwości zamiany pokuty, jeśli okoliczności nie pozwalają na jej wypełnienie. Kanon pochodzi z Penitencjału Egberta:

Gdyby ktoś z powodu swej słabości lub choroby nie mógł zachować postu lub surowości nakazanej mu przez spowiednika, to zezwala się, by swój post zamienił z pobożnością na środki [tego] świata. To znaczy, jeśli ktoś jest bogaty, za 12 miesięcy postu niech da 30 solidów, gdyby nie był tak zamożny, niech da 20 solidów, a jeśli nie jest zbyt bogaty, niech da 10 solidów. Jeśli jest biedny i nie ma 10 solidów, niech da 3, ponieważ bogatemu łatwiej dać 30 niż biednemu $3^{28}$.

Analizowanie kanonów pokutnych rodzi przekonanie, że nakładane pokuty były bardzo surowe, szczególnie w porównaniu z dzisiejszą praktyka spowiedniczą. Pomimo indywidualnego podejścia do każdego penitenta zdarzały się zapewne sytuacje, gdy pokuta nie mogła być w pełni zrealizowana, czasem z powodu choroby. W takich przypadkach penitent mógł sam dokonać zamiany zadanej pokuty, według zacytowanego zamiennika, lub innych opisanych w kanonach penitencjałów ${ }^{29}$. Możliwe również, że zamienniki nie były znane szeroko i po poradę trzeba było udać się do spowiednika.

Choroby w znaczeniu fizycznym nie były głównymi tematami ksiąg pokutnych, dlatego nie znajdujemy w nich opisów przebiegu albo leczenia poszczególnych jednostek chorobowych. Dolegliwości ciała ludzkiego

27 Por. A. Dooley, The Plague and Its Consequences in Ireland, w: Plague and the End of Antiquity. The Pandemic of 541-750, red. L.K. Little, Cambridge 2007, s. 215-228.

28 Sancti Egberti Eboracensis archiepiscopi poenitentiale libri VIV 57, ŹMT 58, s. 237.

29 Szerzej na temat zamienników pokutnych, zob. B.J. Szpetkowska, Zamienniki pokut w ujęciu irlandzkich i brytyjskich ksiag pokutnych, „Polonia Sacra” 24/1 (2020) s. 113-134. 
były wspominane przy kwestiach dotyczących grzechów związanych z leczeniem oraz gdy choroba wymuszała konieczność przerwania albo złagodzenia pokuty.

\section{Podsumowanie}

Księgi pokutne są przede wszystkim cennym źródłem na temat praktyk penitencjalnych Kościoła w później starożytności i wczesnym średniowieczu. Analiza wybranych kanonów pozwala odtworzyć myślenie ówczesnych chrześcijan o grzechu jako o chorobie duszy. W szerokim sensie prawie każdy kanon penitencjałów porusza tę tematykę, jednak niektóre z nich bardzo wyraźnie stosują analogię mówiącą, że tym, czym dla ciała jest choroba, tym dla duszy jest grzech. W konsekwencji tego osoba chorująca na duszy, czyli grzesznik, potrzebuje pomocy lekarza. W takiej sytuacji potrzebny jest wyświęcony kapłan, który może być szafarzem sakramentu pokuty, bo to on w pierwszym rzędzie uważany jest za lekarstwo na grzech. Oprócz tego pomocne są inne sposoby, przez które dokonuje się odpuszczenie grzechów nieuważanych za ciężkie. Dla pojednanych z Bogiem przez spowiedź kolejną formą pomocy jest przyjęcie Eucharystii, która staje się lekarstwem chroniącym od dalszych upadków w grzechy.

Ponieważ człowiek jest jednością duszy i ciała, twórcy penitencjałów nie pomijają ludzkich dolegliwości fizycznych, chociaż nie one są głównym tematem dzieł. Autorzy ksiąg pokutnych przestrzegają przed grzesznym sposobem leczenia dolegliwości i wskazują, że choroba jest okolicznością, przez którą nałożona już pokuta może zostać złagodzona. W penitencjałach zostaje także powtórzona zachęta, by zgodnie ze zwyczajem odwiedzać i troszczyć się o chorych, także podczas epidemii. W tym kontekście, mimo upływu lat, treść irlandzkich i brytyjskich ksiąg pokutnych nie przestała być aktualna, szczególnie w obecnych dniach, gdy cały świat zmaga się z trwającą pandemią.

\section{Illnesses of the Human Soul and Body according to British and Irish Penitential Books}

(summary)

The reality of illness is inscribed in human life. It affects both the human body, in the form of various ailments and indispositions, and, through sin, it touches his soul in an analogous 
way. Since human being consists unity, he must take care of both the body and the soul, without neglecting any element that makes up his humanity. In this article, the author answers the question of how the illness of the soul and body of man were understood in the Christian antiquity in the Irish Church. To achieve this goal, he analysed selected canons from Irish and British penitential books. Penitencials mainly concern the religious life of the people of that time, therefore the analysis revealed more information about the spiritual illness, that is sin and the medications for its treatment. As far as the source material allowed, the analysis also took into account the physical aspect of the disease. The method used allowed to draw a picture of the disease of the human soul and body in late antiquity, based on Irish and British penitential books.

Keywords: illness; sin; Irishmen; medicine; penitentials; penance; confession

\title{
Choroby duszy i ciała człowieka według brytyjskich i irlandzkich ksiąg pokutnych
}

\author{
(streszczenie)
}

W życie człowieka wpisana jest rzeczywistość choroby. Dotyka ona zarówno ciała ludzkiego w postaci różnych dolegliwości i niedomagań, jak również przez grzech dotyka w analogiczny sposób jego duszy. Ponieważ człowiek jest jednością, musi troszczyć się o aspekt cielesny oraz duchowy, nie pomijając żadnego elementu składającego się na jego człowieczeństwo. W niniejszym artykule autor odpowiada na pytanie, w jaki sposób w starożytności chrześcijańskiej w Kościele Iroszkockim rozumiano choroby duszy i ciała człowieka. Dla osiągnięcia tego celu dokonał analizy wybranych kanonów z irlandzkich i brytyjskich ksiąg pokutnych. Penitencjały dotyczą przede wszystkim życia religijnego ówczesnych ludzi, dlatego analiza pozwoliła wydobyć głównie informacje na temat duchowej choroby, czyli grzechu, oraz lekarstw pozwalających na jego leczenie. $\mathrm{Na}$ ile pozwalał na to materiał źródłowy, w analizie uwzględniono również fizyczny aspekt choroby. Zastosowana metoda pozwoliła nakreślić obraz choroby duszy i ciała człowieka w późnej starożytności w oparciu o irlandzkie i brytyjskie księgi pokutne.

Słowa kluczowe: choroba; grzech; Iroszkoci; lekarstwo; penitencjały; pokuta; spowiedź

\section{Bibliografia}

\section{Źródła}

Capitula Dacheriana, tł. A. Caba, Capitula Dacheriana, w: Ksiegi pokutne (tekst łaciński, grecki i polski), opr. A. Baron - H. Pietras, Synody i Kolekcje Praw 5, ŹMT 58, Kraków 2011, s. 115-131.

Capitula Theodori, tł. A. Baron - A. Caba, Rozdziały Teodora, w: Księgi pokutne (tekst taciński, grecki i polski), opr. A. Baron - H. Pietras, Synody i Kolekcje Praw 5, ŹMT 58, Kraków 2011, s. 161-180. 
Columbanus, De diversitate culparum, tł. S. Kalinkowski, Kolumban, O różnych przewinieniach, w: Księgi pokutne (tekst łaciński, grecki i polski), opr. A. Baron H. Pietras, Synody i Kolekcje Praw 5, ŹMT 58, Kraków 2011, s. 38-47.

Discipulus Umbriensium, tł. A. Baron, Discipulus Umbriensium, w: Księgi pokutne (tekst łaciński, grecki i polski), opr. A. Baron - H. Pietras, Synody i Kolekcje Praw 5, ŹMT 58, Kraków 2011, s. 131-160.

Excarpsum de canonibus catholicorum Patrum vel Poenitential ad remedium animarum domini Egberti archiepiscopi Eburacae civitatis, tł. A. Baron - A. Caba, Wyciag z kanonów Ojców katolickich lub pokutne środki lecznicze dla dusz, arcybiskupa Egberta z Yorku, w: Księgi pokutne (tekst łaciński, grecki i polski), opr. A. BaronH. Pietras, Synody i Kolekcje Praw 5, ŹMT 58, Kraków 2011, s. 181-193.

Paenitentiale quod dicitur Bigotianum, tł. A. Caba, Penitencjał zwany Bigotianum, w: Księgi pokutne (tekst łaciński, grecki i polski), opr. A. Baron - H. Pietras, Synody i Kolekcje Praw 5, ŹMT 58, Kraków 2011, s. 249-259.

Paenitentiale Sancti Columbani, tł. S. Kalinkowski, Ksiega pokutna św. Kolumbana, w: Księgi pokutne (tekst łaciński, grecki i polski), opr. A. Baron - H. Pietras, Synody i Kolekcje Praw 5, ŹMT 58, Kraków 2011, s. 31-37.

Poenitentiale Cummaeani, tł. A. Baron - J. Łukaszewska-Haberko - H. Pietras, Księga pokutna Kummeana, w: Ksieggi pokutne (tekst łaciński, grecki i polski), opr. A. Baron - H. Pietras, Synody i Kolekcje Praw 5, ŹMT 58, Kraków 2011, s. 70-85.

Poenitentiale Pseudo-Cummaeani, tł. A. Baron - J. Łukaszewska-Haberko - H. Pietras, Księga pokutna Pseudo-Kummeana, w: Księgi pokutne (tekst taciński, grecki i polski), opr. A. Baron - H. Pietras, Synody i Kolekcje Praw 5, ŹMT 58, Kraków 2011, s. 86-114.

Poenitentiale Vinniani, tł. A. Baron - J. Łukaszewska-Haberko - H. Pietras, Księga Pokutna Finniana, w: Księgi pokutne (tekst łaciński, grecki i polski), opr. A. Baron - H. Pietras, Synody i Kolekcje Praw 5, ŹMT 58, Kraków 2011, s. 14-24.

Sancti Egberti Eboracensis archiepiscopi poenitentiale libri V, tł. A. Baron - J. Łukaszewska-Haberko - H. Pietras, Penitencjat św. Egberta arcybiskupa Yorku w pięciu księgach, w: Księgi pokutne (tekst łaciński, grecki i polski), opr. A. Baron - H. Pietras, Synody i Kolekcje Praw 5, ŹMT 58, Kraków 2011, s. 201-245.

Synodusalia S. Patricii, tł. B. Frontczak, Drugi synod świętego Patryka, w: Księgi pokutne (tekst łaciński, grecki i polski), opr. A. Baron - H. Pietras, Synody i Kolekcje Praw 5, ŹMT 58, Kraków 2011, s. 65-69.

\section{Opracowania}

Cahill T., How the Irish saved civilizaion. The Untold Story of Ireland's Heroic Role from the Fall of Rome to the Rise of Medieval Europe, New York 1995.

Daniélou J. - Marrou H.I., Historia Kościoła, Od początków do roku 600, t. 1, tł. M. Tarnowska, Warszawa 1986. 
Dooley A., The Plague and Its Consequences in Ireland, w: Plague and the End of Antiquity. The Pandemic of 541-750, red. L.K. Little, Cambridge 2007, s. 215-228.

El-Radhi A.S., History of Fever, w: Clinical Manual of Fever in Children, red. J. Caroll - A.S. El-Radhi - N. Klein, Berlin 2009, s. 287-298.

Jougan A., Słownik kościelny łacińsko-polski, Sandomierz 2013.

Katolo A.J., Koncepcje zdrowia i choroby w starożytnej kulturze klasycznej $i$ w ujęciu biblijnym. Próba porównania, „Studia Gdańskie” 24 (2009) s. 195-209.

Kieling M., Grzech i pokuta a świadomość świętości w późnej starożytności chrześcijańskiej, „Teologia Patrystyczna” 1 (2004) s. 43-54.

Kieling M., Dwanaście sposobów odpuszczenia grzechów? Praktyka pokutna wczesnośredniowiecznego Kościoła na podstawie „Penitencjału Egberta”, „Teologia praktyczna" 13 (2012) s. 83-95.

Kieling M., Zasady ogólne dotyczace praktyk pokutnych na podstawie „Libri poenitentales”, „Vox Patrum” 67 (2017) s. 225-240.

Kosecki B., Wyznanie grzechów w praktyce pokuty Kościoła na Zachodzie, „Ruch Biblijny i Liturgiczny” 29/2-3 (1976) s. 65-81.

Kwiatkowski D., Rzeczywistość grzechu i praktyki pokutne w Paenitentiale Vigilianum (Albeldense), „Liturgia Sacra” 18/1 (2002) s. 113-126.

Misiarczyk L., Osiem duchów zła i sposoby walki z nimi według Ewagriusza z Pontu, Kraków 2015.

Strzelczyk J., Iroszkoci w kulturze średniowiecznej Europy, Warszawa 1987.

Szpetkowska B.J., Zamienniki pokut w ujęciu irlandzkich i brytyjskich ksiag pokutnych, „Polonia Sacra” 24/1 (2020) s. 113-134.

Wołek A.M., Metaforyka i symbolika krwi w tradycji antycznej, w: Źródła Humanistyki Europejskiej, t. 6, red. K. Korus, Kraków 2013, s. 209-218.

Worbs M., Leczniczy charakter sakramentu pokuty, w: Wiara a zdrowie (II), red. L. Sochocka - M. Worbs, Opole 2016, s. 91-106.

Zawadzki W., Bernharda Poschmanna nauka o pokucie wczesnośredniowiecznej, „Studia Warmińskie” 47 (2010) s. 181-195. 